Archive for

Organic Chemistry

Arkivoc 2019, part iii, 67-78

\title{
An efficient one-pot synthesis of 2,5-disubstituted-1,3,4-thiadiazoles from aldehydes and hydrazides using Lawesson's reagent
}

\author{
Inseok Ko, Soojin Park, Goeun Lee, and Hakwon Kim* \\ Department of Chemistry and Global Center for Pharmaceutical Ingredient Materials, \\ Kyung Hee University, Gyonggi-do 1732, Korea \\ Email: hwkim@khu.ac.kr
}

This article dedicated to Professor George A. Kraus, in honor of his distinguished career in synthetic organic chemistry

Received 01-06-2019

Accepted 02-10-2019

Published on line $02-13-2019$

\begin{abstract}
Five-membered heterocyclic-ring systems, such as thiadiazoles, remain an important and prevalent scaffold in the development of novel leads in medicinal chemistry for a variety of therapeutic targets. A two-step, onepot synthesis of 2,5-disubstituted-1,3,4-thiadiazole derivatives from aryl hydrazides and aryl aldehydes using Lawesson's reagent is described, yielding 2,5-disubstituted-1,3,4-thiadiazoles in moderate-to-high yields. Based on preliminary biological experiments, some of the newly synthesized thiadiazoles show antioxidant activity.
\end{abstract}

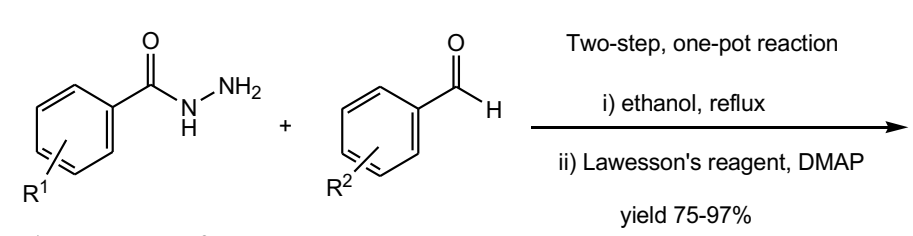

$\mathrm{R}^{1}=\mathrm{H}, \mathrm{OCH}_{3}, \quad \mathrm{R}^{2}=\mathrm{H}$, halogen, $\mathrm{OCH}_{3},\left(\mathrm{OCH}_{3}\right)_{2}, \mathrm{Et}$

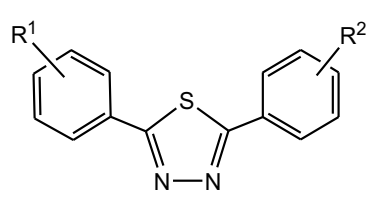

2,5-diaryl-1,3,4-thiadiazoles

Keywords: $1,3,4$-Thiadiazole, Lawesson's reagent, $N$-acylhydrazone, $N$-aroylhydrazone, dimethylaminopyridine 


\section{Introduction}

Heterocyclic compounds are defined, according to IUPAC (International Union of Pure and Applied Chemistry), as cyclic compounds including at least two different atoms such as oxygen, sulfur or nitrogen in the ring. These compounds are important due to their wide range of biological activities. For example, the antiviral Sovaldi (Gilead Sciences), the antipsychotic Abilify (Otsuka), and the anti-inflammatory Nexium are among the most popular and widely used drugs worldwide. ${ }^{1}$

Among the heterocyclic compounds, 1,3,4-thiadiazole has attracted special interest in recent years in various areas, including pharmaceutical, agricultural, and materials chemistries. 1,3,4-Thiadiazole is a weak base due to the inductive effect of the sulfur in the ring, and possesses a relatively high aromaticity. ${ }^{2,3,4}$ In addition, the ring is electron deficient due to the electron-withdrawing effects of the nitrogen atoms. ${ }^{2}$ For these reasons, In the pharmaceutical field, 1,3,4-thiadiazole derivatives are known to exhibit diverse biological activities, such as antimicrobial ${ }^{5}$, antiviral ${ }^{6}$, anticonvulsant ${ }^{7}$, antifungal, ${ }^{8-10}$ antitubercular, ${ }^{11-13}$ anticancer, ${ }^{14}$ and immunomodulatory ${ }^{15}$ activities. Some examples of commercially-available drugs containing the 1,3,4thiadiazole ring are Megazol, Acetazolamide (Diamox), Furidiazine, and Desaglybuzole, shown in Figure $1 .{ }^{16,17}$

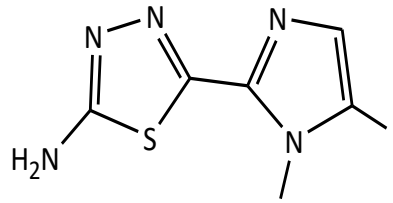

Megazol

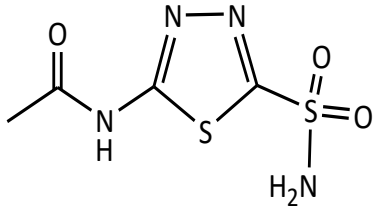

Acetazolamide (Diamox)

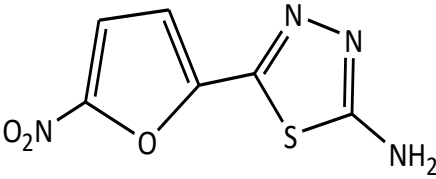

Furidiazine

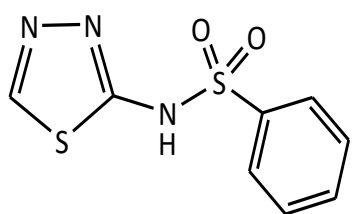

Desaglybuzole

Figure 1. Commercially available 1,3,4-thiadiazole drugs

Synthetic methods to produce 1,3,4-thiadiazoles have been developed and studied over many decades due to the interest following the discovery of their diverse pharmacological and physiological activities. Wellknown synthetic methods for 1,3,4-thiadiazoles include starting materials such as $N, N^{\prime}$-diacylhydrazines, ${ }^{18,19}$ thiosemicarbazides ${ }^{20}$ or thiohydrazides, ${ }^{21,22}$ as well as the transformation of 1,3,4-oxadiazoles. ${ }^{23}$ Most existing synthetic methods, however, require harsh conditions, multi-step procedures, and scarce starting materials or experience difficulty in forming non-symmetric 1,3,4-thiadiazoles. Therefore, it is still necessary to develop a more efficient synthetic method to produce 1,3,4-thiadiazoles. We, herein, report a highly efficient, two-step, one-pot synthetic method for 2,5-disubstituted-1,3,4-thiadiazoles from aldehydes and hydrazides in good-toexcellent yields using a sequence of $\mathrm{N}$-aroylhydrazone formation, thionation, cyclization and oxidation.

\section{Results and Discussion}

Originally, we thought that the synthesis of 1,3,4-thiadazole (5) could be brought about in a three-step reaction sequence. In Scheme 1, we illustrate the formation of the aroylhydrazone (3) from the corresponding hydrazide (1) and aldehyde (2), followed by thionation of $\mathbf{3}$ with Lawesson's reagent (LR) ${ }^{24-26}$ to give a thiohydrazide intermediate (4). Oxidative cyclization of 4 using an oxidant such as $I_{2}$, [bis(trifluoroacetoxy)iodobenzene] (PIFA) or $\mathrm{FeCl}_{3}$ yields the disubstituted-1,3,4-thiadiazole (5). 


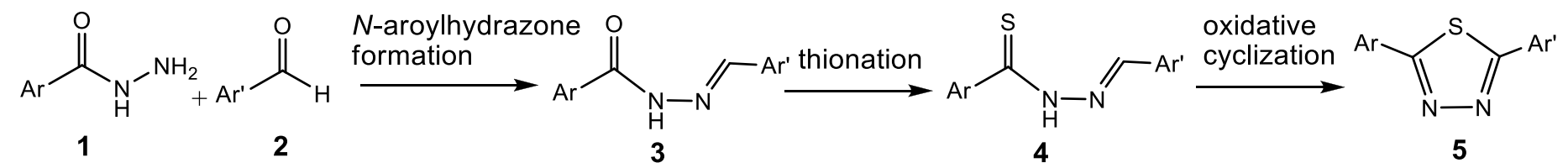

Scheme 1: 1,3,4-thiadiazoles from aryl aldehydes and hydrazides in a three-step sequence

When compound 3 was treated with LR, however, the disubstituted-1,3,4-thiadiazole (5) was formed directly without oxidant, and with separation of the thiohydrazide (4). Therefore, we studied a two-step, onepot synthesis of 2,5-diphenyl-1,3,4-thiadiazole (5a) from benzoylhydrazide (1a) and benzaldehyde (2a) without isolation of the $\mathrm{N}$-benzoylhydrazone (3a) (Scheme 2). After refluxing for 2 hours, the ethanol was evaporated in vacuo. To the reaction mixture of crude 3a (0.1 M) in solvent, LR was added, followed by addition of a base. In other trials, we omitted addition of the base. The resulting mixture was refluxed for 10 hours.

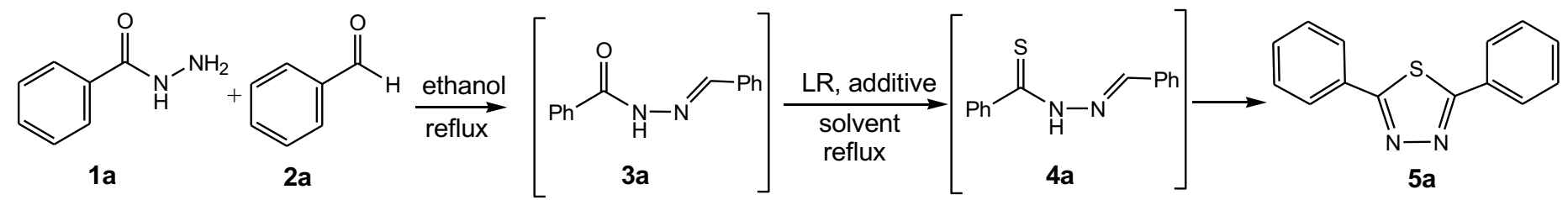

Scheme 2. Two-step, one-pot synthesis of 2,5-diphenyl-1,3,4-thiadiazole (5a) from benzoylhydrazide (1a) and benzaldehyde (2a) without separation of the $N$-benzoylhydrazone (3a) using LR

To determine the optimal procedure with solvents, thionating agents or additives, this one-pot reaction was investigated under several conditions (Table 1). 
Table 1. Optimization of the synthesis of 2,5-diphenyl-1,3,4-thiadiazole (5a) from benzoylhydrazide (1a) and benzaldehyde $(2 \mathbf{a})^{\mathrm{a}}$

\begin{tabular}{ccccc}
\hline Entry & Thionating reagent [eq] & Solvent & Additive [eq] & Yield (\%) $^{\text {b }}$ \\
\hline 1 & LR [0.5] & Toluene & - & 68 \\
2 & LR [0.8] & Toluene & - & 79 \\
3 & LR [1.0] & Toluene & - & 65 \\
4 & LR [0.8] & THF & - & 60 \\
5 & LR [0.8] & Ethanol & - & - \\
6 & LR [0.8] & Toluene & 2,6-lutidine [1.2] & 73 \\
7 & LR [0.8] & Toluene & DBU [1.2] & 79 \\
8 & LR [0.8] & Toluene & Piperidine [1.2] & 85 \\
9 & LR [0.8] & Toluene & DMridine [1.2] & 77 \\
10 & LR [0.8] [1.2] & 96 \\
11 & LR [0.8] & Toluene & DMAP [1.0] & 86 \\
12 & LR [0.8] & Toluene & DMAP [1.6] & 70 \\
$13^{c}$ & LR [0.8] & Toluene & DMAP [1.2] & 70 \\
14 & P $S_{10}[0.8]$ & Toluene & DMAP [1.2] & 13 \\
\hline
\end{tabular}

${ }^{a}$ The reaction was accomplished with a corresponding aldehyde and hydrazide in ethanol at room temperature.

After refluxing for $2 \mathrm{hr}$, the ethanol was evaporated in vacuo. To a remaining crude 3a, LR and solvent were added, followed by addition of a base. The resulting mixture was refluxed for $10 \mathrm{hr}$.

${ }^{\mathrm{b}}$ Isolated yield.

${ }^{c}$ Two-pot synthesis including separation of $\mathbf{3 a}$.

Initially, the reaction was started with 0.5 equivalent of $\mathbf{L R}$, since, stoichiometrically, one equivalent of $\mathbf{L R}$ produces two equivalents of dithiophosphine ylides to thionate a carbonyl group. ${ }^{24-26}$ When 0.5 equivalent of LR was used, 2,5-diphenyl-1,3,4-thiadiazole (5a) was produced in $68 \%$ yield (Table 1, entry 1). The amount of LR was gradually increased to 0.8 or 1.0 equivalent (Table 1 , entries $2-3$ ). The highest yield (79\%) was obtained using 0.8 equivalent of LR (Table 1, entry 2). When tetrahydrofuran (THF), which is more polar than toluene, was used, the yield was only $60 \%$. No reaction occurred when ethanol was used (Table 1, entry 5). Next, the base-additive effect was investigated by adding various bases, while maintaining the amount of LR at 0.8 equivalent in refluxing toluene as described above. When using bases such as 2,6-lutidine, 1,8diazabicyclo[5.4.0]undec-7-ene (DBU), piperidine, pyridine, and dimethylaminopyridine (DMAP), the number of byproducts were lower, and the yields were similar or higher than those in the trials omitting the bases. The highest yield (96\%) was obtained when 1.2 equivalents of DMAP were used (Table 1, entry 10), and was superior compared to 1.0 equivalent or 1.6 equivalents of DMAP (Table 1, entries 11-12). On the other hand, the two-step synthesis involving separation of $N$-aroylhydrazone (3) showed a lower overall yield of $70 \%$ than the one-pot synthesis (Table 1 , entry 13 ). Using another thionating reagent, $\mathrm{P}_{4} \mathrm{~S}_{10}$, yielded only $13 \%$ of the desired product (Table 1, entry 14).

Based on the previous experimental results and the literature, ${ }^{27}$ the mechanism of this reaction can be proposed as shown in Scheme 3. Following formation of the $N$-aroylhydrazone intermediate (3), it would react with LR to give the thiohydrazone (4). It is believed that dihydrothiadiazole $\left(\mathbf{4}^{\prime}\right)$, which is the preferred 
tautomeric form of the thiohydrazone (4), is readily oxidized to produce the disubstituted-1,3,4-thiadiazole (5).

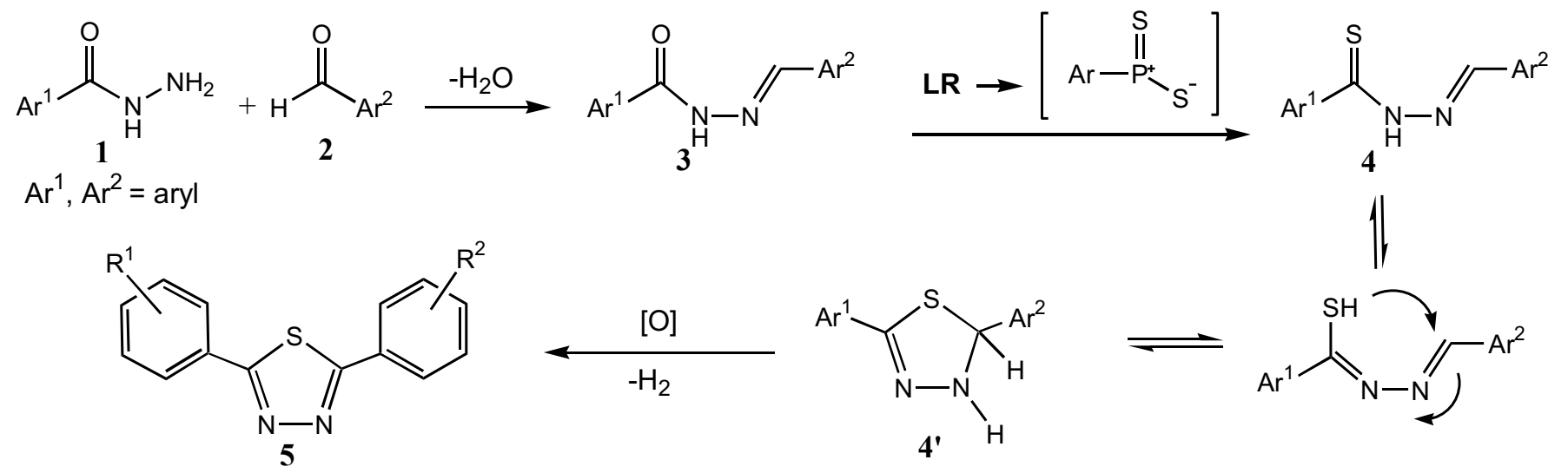

Scheme 3. Proposed mechanism for formation of the 1,3,4-thiadiazoles.

To clarify the mechanism of this reaction, we needed to prove formation of intermediate 4 and/or 4'. Therefore, we synthesized compounds 4 and 4' by the known literature method. ${ }^{27-29}$ After the reaction of the phenyl thiohydrazide (9) with benzaldehyde (2a), the ring tautomer dihydrothiadiazole (4') was obtained, rather than the thiohydrazone (4) (Scheme 4). This was confirmed by analyzing ${ }^{1} \mathrm{H}$ and ${ }^{13} \mathrm{C}$ NMR spectra compared with the spectral data from a previous study. ${ }^{29}$ During our one-pot reaction, a TLC spot of dihydrothiadiazole (4') was also observed below the spot of 2,5-diphenyl-1,3,4-thiadiazole (5a). In addition, a small amount of 4' was isolated and its structure confirmed. As a result, it is suggested that the dihydrothiadiazole intermediate (4') is directly formed from 3, and immediately oxidized under the reaction conditions to produce 2,5-diphenyl-1,3,4-thiadiazole (5a).

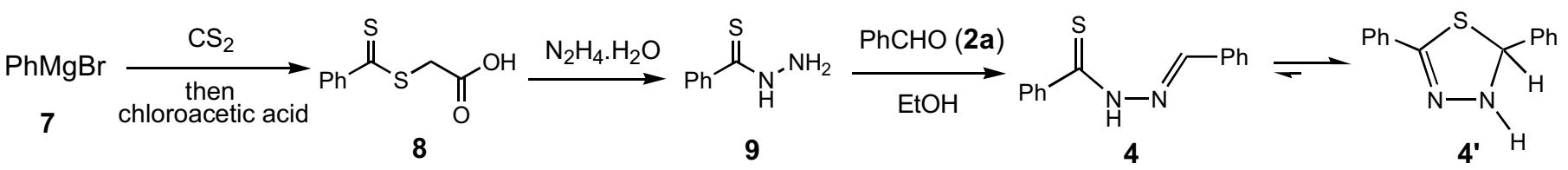

Scheme 4. Results of literature method for synthesis of intermediates 4 and/or 4'

As mentioned above, the use of a base is, presumably, to inhibit the reverse reaction of $N$-acylhydrazones (3) to aldehydes (2) and hydrazides (1), and, thereby, improve the overall yield of the reaction. Also, according to the literature, pyridine has been reported to stabilize and activate the phosphine ylide by forming stable complexes with $\mathrm{P}_{4} \mathrm{~S}_{10}{ }^{30}$ and Woollins reagents (WR), ${ }^{31}$ which has a structure similar to $\mathbf{L R}$. LR is known to be in equilibrium with its dithiophosphine ylide in solution (Figure 2). This ylide is said to be the reactive intermediate in the thionation processes with LR. ${ }^{24-26}$ Therefore, we hypothesized that DMAP would protect the inverse-hydrolysis reaction of $\mathrm{N}$-acylhydrazone (3), stabilize and activate LR by forming a stable DMAPdithiophosphine complex like pyridine. 


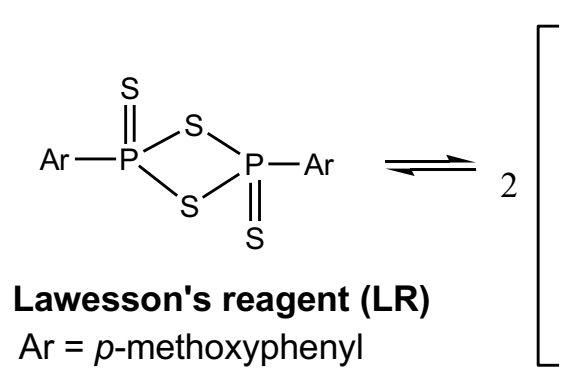<smiles>S=P([S-])(SP(=S)(S)[n+]1ccccc1)[n+]1ccccc1</smiles>

$\mathrm{P}_{4} \mathrm{~S}_{10}$-Py complex

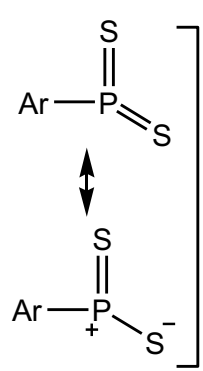

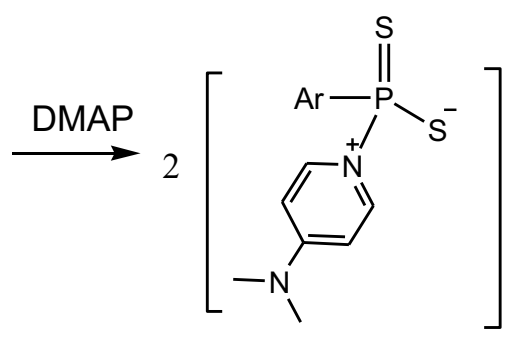<smiles>[R6][As][PH](=[Se])(=[Se])c1ccccc1</smiles>

WR-Py complex

Figure 2. Proposed structures of DMAP-LR, $\mathrm{P}_{4} \mathrm{~S}_{10}-\mathrm{Py}$, and WR-Py complexes

To extend the one-pot synthetic method to various 1,3,4-thiadiazoles (5), different combinations of aroylhydrazides (1a-n) and benzaldehydes (2a-n) were reacted under the same conditions as $\mathbf{5 a}$. First, the same amounts of aldehyde and hydrazide were reacted in refluxing ethanol for two hours. After the ethanol was evaporated, the remaining crude thiahydrazone (3) in the reaction vessel was reacted in toluene, refluxing with 0.8 equivalent of LR and 1.2 equivalents of DMAP for 12 hours as shown in Scheme 5.<smiles>[R]c1ccc(C(=O)NN)cc1</smiles>

1<smiles>O=Cc1ccccc1</smiles>

2<smiles>[R]c1ccc(-c2nnc(-c3ccc([R])cc3)s2)cc1</smiles>

5

Scheme 5. Synthesis of 2,5-diphenyl-1,3,4-thiadiazole derivatives (5). Note: Benzaldehyde (1.0 mmol) and benzoylhydrazide $(1.0 \mathrm{mmol})$ were refluxed in ethanol for $2 \mathrm{hr}$, evaporated in vacuo, and then reacted with $\mathbf{L R}$ and DMAP in refluxing toluene.

A series of 2,5-disubstituted-1,3,4-thiadiazoles (5a-m) were prepared in moderate-to-high yields (75\% to $97 \%)$ from hydrazides (1a-n) and aldehydes (2a-n), the results of which are summarized in Table 2. 
Table 2: Results of reactions of hydrazides (1) and benzaldehydes (2) to yield 2,5-disubstituted-1,3,4thiadiazole compounds (5)

\begin{tabular}{|c|c|c|c|c|c|}
\hline Entry & Product & $\begin{array}{l}\text { Yield } \\
(\%)^{a}\end{array}$ & Entry & Product & Yield (\%) \\
\hline$z$ & N & 96 & 8 & & 89 \\
\hline 2 & $N-N$ & 97 & 9 & & 80 \\
\hline 3 & $5 c$ & 93 & 10 & & 85 \\
\hline 4 & & 87 & 11 & & 84 \\
\hline 5 & $-{ }^{n} \quad 5 e$ & 93 & 12 & & 78 \\
\hline 6 & & 85 & 13 & & 75 \\
\hline 7 & $\mathrm{~N}-\mathrm{N} \quad 5 \mathrm{~g}$ & 80 & 14 & & 85 \\
\hline
\end{tabular}

${ }^{\mathrm{a}}$ Isolated yield by flash column chromatography.

In summary, a two-step, one-pot reaction was accomplished in refluxing ethanol using the same amounts of hydrazide $\mathbf{1}$ and aldehyde $\mathbf{2}$ without separating the hydrazine intermediate $\mathbf{3}$, and in the absence of added oxidant.

\section{Conclusions}

In conclusion, we have developed a highly efficient, two-step, one-pot synthesis of 2,5-disubstituted-1,3,4thiadiazoles in moderate-to-high yields from benzaldehydes and hydrazines using LR in the absence of an 
additional oxidant. Based on the confirmation of the formation of thiadiazoline intermediate, a reaction mechanism has been proposed and the role of the base additives in this reaction has been suggested. According to preliminary biological experiments, some of the newly synthesized thiadiazoles show antioxidant activity. These results will be presented in a future study.

\section{Experimental Section}

\section{General.}

Melting points were determined using a Barnstead Electrothermal 9100 melting point apparatus. ${ }^{1} \mathrm{H}$ NMR and ${ }^{13} \mathrm{C}$ NMR spectra were recorded on a JEOL $300 \mathrm{MHz}$ spectrometer and JEOL $75 \mathrm{MHz}$ spectrometer, respectively. Chemical shifts $(\delta)$ are reported in parts per million $(p p m)$ and coupling constants $(J)$ in $\mathrm{Hertz}(\mathrm{Hz})$. The following abbreviations were used to explain the multiplicities: $s=$ singlet, $d=$ doublet, $t=$ triplet, $q=$ quartet, $m=$ multiplet, $b r s=$ broad singlet. High resolution mass spectrometry (HRMS) was performed using a JEOL JMS-700 M station mass spectrometer and electron impact ionization (El-magnetic sector) mass spectrometer.

\section{General procedure for synthesis of compounds $5 \mathrm{a}-5 \mathrm{~m}$}

In a round bottom flask, corresponding aldehyde (2) $(1.0 \mathrm{mmol})$ and hydrazide (1) $(1.0 \mathrm{mmol})$ were added in ethanol $(5.0 \mathrm{ml})$ at room temperature. The reaction mixture was refluxed for $2 \mathrm{hr}$. The ethanol was evaporated in vacuo. To the resulting crude product (3), Lawesson's reagent $(0.8 \mathrm{mmol}, 0.8 \mathrm{eq})$ and toluene $(10 \mathrm{ml})$ were added, followed by 4-(dimethylamino)pyridine $(1.2 \mathrm{mmol}, 1.2 \mathrm{eq})$. The resulting mixture was refluxed for 10 to $15 \mathrm{hr}$ until 2,5-diphenyl-2,3-dihydro-1,3,4-thiadiazole was not detected by TLC. After evaporation of toluene, the residue was purified by flash-column chromatography.

2,5-Diphenyl-1,3,4-thiadiazole (5a) 32, 33 [CAS No. 1456-21-9]. White solid; Yield: 96\%; mp 134-135 ${ }^{\circ} \mathrm{C}$ (Lit. 140 or $\left.132{ }^{\circ} \mathrm{C}\right) ;{ }^{1} \mathrm{H}$ NMR $\left(300 \mathrm{MHz}, \mathrm{CDCl}_{3}\right) \delta(\mathrm{ppm})$ 7.47-7.56 (m, 4H), 7.98-8.07 (m, $\left.4 \mathrm{H}\right) ;{ }^{13} \mathrm{C} \mathrm{NMR}\left(75 \mathrm{MHz} \mathrm{CDCl}_{3}\right) \delta$ (ppm) 127.98, 129.23, 130.24, 131.15, 168.23 (thiadiazole C)

2-(4-Fluorophenyl)-5-phenyl-1,3,4-thiadiazole (5b)33 [CAS No. 16020385-48-9]. White solid; Yield: 97\%; mp 174-175 ${ }^{\circ} \mathrm{C}$ (Lit. $\left.173{ }^{\circ} \mathrm{C}\right){ }^{1} \mathrm{H}$ NMR $\left(300 \mathrm{MHz}, \mathrm{CDCl}_{3}\right) \delta(\mathrm{ppm}) 7.21(t, J 8.5 \mathrm{~Hz}, 2 \mathrm{H}), 7.48-7.55(m, 3 \mathrm{H}), 7.98-8.07$ $(\mathrm{m}, 4 \mathrm{H}) ;{ }^{13} \mathrm{C}$ NMR $\left(75 \mathrm{MHz}, \mathrm{CDCl}_{3}\right) \delta$ (ppm) 116.27, 116.56, 127.97, 129.25, 130.01, 131.23, 162.83, 166.17 (FPhenyl-4-C), 166.99 (thiadiazole C), 168.28 (thiadiazole C)

2-(4-Chlorophenyl)-5-phenyl-1,3,4-thiadiazole (5c) ${ }^{32}$ [CAS No. 17453-22-4]: White solid; Yield: 93\%; mp 177$178{ }^{\circ} \mathrm{C}$ (Lit. $\left.180{ }^{\circ} \mathrm{C}\right) .{ }^{1} \mathrm{H}$ NMR $\left(300 \mathrm{MHz}, \mathrm{CDCl}_{3}\right) \delta(\mathrm{ppm})$ 7.41-7.56 (m, $\left.5 \mathrm{H}\right), 7.89-8.06(m, 4 \mathrm{H}) ;{ }^{13} \mathrm{C} \mathrm{NMR} \mathrm{(75}$ $\left.\mathrm{MHz}, \mathrm{CDCl}_{3}\right) \delta$ (ppm) 128.01, 128.71, 129.11, 129.28, 129.53, 130.05, 131.32, 137.28, 166.98 (thiadiazole C), 168.49 (thiadiazole $\mathrm{C}$ )

2-(4-Bromophenyl)-5-phenyl-1,3,4-thiadiazole (5d) ${ }^{33}$ [CAS No. 17453-23-5]. White solid; Yield: 87\%; mp 153$154{ }^{\circ} \mathrm{C}$ (Lit. $\left.152{ }^{\circ} \mathrm{C}\right) .{ }^{1} \mathrm{H}$ NMR $\left(300 \mathrm{MHz}, \mathrm{CDCl}_{3}\right) \delta(\mathrm{ppm}) 7.51-7.53(\mathrm{~m}, 3 \mathrm{H}), 7.65(d, J 8.6 \mathrm{~Hz}, 2 \mathrm{H}), 7.90(d, J 8.6$ $\mathrm{Hz}, 2 \mathrm{H}), 8.02$ (dd, J 6.6, $2.9 \mathrm{~Hz}, 2 \mathrm{H}) ;{ }^{13} \mathrm{C} \mathrm{NMR}\left(75 \mathrm{MHz}, \mathrm{CDCl}_{3}\right) \delta$ (ppm) 125.77, 128.18, 129.31, 129.46, 130.20, $131.50,132.66,167.24$ (thiadiazole C), 168.69 (thiadiazole C)

2-(4-Methoxyphenyl)-5-phenyl-1,3,4-thiadiazole (5e) ${ }^{33}$ [CAS No. 1456-67-3]. White solid; Yield: 93\% from phenylhydrazide and 4-methoxybenzaldehyde, 89\% from 4-methoxybenzohydrazide and benzaldehyde; mp137-138 ${ }^{\circ} \mathrm{C}$ (Lit. $\left.136{ }^{\circ} \mathrm{C}\right) .{ }^{1} \mathrm{H}$ NMR $\left(300 \mathrm{MHz}, \mathrm{CDCl}_{3}\right) \delta(\mathrm{ppm}) 3.85(\mathrm{~s}, 3 \mathrm{H}), 6.96-7.05$ (m, $\left.2 \mathrm{H}\right), 7.43-7.54(\mathrm{~m}, 3$ $\mathrm{H}), 7.91-8.05(\mathrm{~m}, 4 \mathrm{H}) ;{ }^{13} \mathrm{C} \mathrm{NMR}\left(75 \mathrm{MHz} \mathrm{CDCl}_{3}\right) \delta$ (ppm) 55.60, 114.77, 123.13, 128.08, 129.37, 129.73, 130.58, 131.15, 162.22 (MeO-Phenyl-4-C), 167.62 (thiadiazole C), 168.19 (thiadiazole C) 
2-(3,5-Dimethoxyphenyl)-5-phenyl-1,3,4-thiadiazole (5f). White solid; Yield: 85\%; mp 144-145 ${ }^{\circ} \mathrm{C} .{ }^{1} \mathrm{H}$ NMR $\left(300 \mathrm{MHz}, \mathrm{CDCl}_{3}\right) \delta(\mathrm{ppm}) 3.88(\mathrm{~s}, 6 \mathrm{H}), 6.60(t, J 2.2 \mathrm{~Hz}, 1 \mathrm{H}), 7.18(d, J 2.2 \mathrm{~Hz}, 2 \mathrm{H}), 7.47-7.55(m, 3 \mathrm{H}), 8.01$ $(d d, J ~ 6.6,2.9 \mathrm{~Hz}, 2 \mathrm{H}) ;{ }^{13} \mathrm{C} \mathrm{NMR}\left(75 \mathrm{MHz}, \mathrm{CDCl}_{3}\right) \delta$ (ppm) 55.73, 103.56, 106.02, 128.14, 129.39, 130.35, 131.36, 131.97, 161.42, 168.36 (thiadiazole C), 168.48 (thiadiazole C); HRMS (El+): $\mathrm{m} / z$ Calcd. for $\mathrm{C}_{16} \mathrm{H}_{14} \mathrm{~N}_{2} \mathrm{O}_{2} \mathrm{~S}^{+}$: 298.0776; found: 298.0764

2-(4-Ethylphenyl)-5-phenyl-1,3,4-thiadiazole (5g). White solid; Yield: 80\%; mp 90-91 ${ }^{\circ} \mathrm{C} .{ }^{1} \mathrm{H} \mathrm{NMR}(300 \mathrm{MHz}$, $\left.\mathrm{CDCl}_{3}\right) \delta(\mathrm{ppm}) 1.28(t, J 7.6 \mathrm{~Hz}, 3 \mathrm{H}), 2.72(q, J 7.7 \mathrm{~Hz}, 2 \mathrm{H}), 7.33(d, J 8.3 \mathrm{~Hz}, 2 \mathrm{H}), 7.44-7.57(m, 3 \mathrm{H}), 7.93(d, J$ $8.3 \mathrm{~Hz}, 2 \mathrm{H}), 7.97-8.06(\mathrm{~m}, 2 \mathrm{H}) ;{ }^{13} \mathrm{C} \mathrm{NMR}\left(75 \mathrm{MHz}, \mathrm{CDCl}_{3}\right) \delta(\mathrm{ppm}) 15.18,28.75,127.74,127.96,128.02$, $128.75,129.21,130.35,131.05,147.94,167.84$ (thiadiazole C), 168.38 (thiadiazole C) ; HRMS (El+): $\mathrm{m} / z \mathrm{Calcd}$. for $\mathrm{C}_{16} \mathrm{H}_{14} \mathrm{~N}_{2} \mathrm{~S}^{+}: 266.0878$; found: 266.0872

2-(4-Fluorophenyl)-5-(4-methoxyphenyl)-1,3,4-thiadiazole (5h). White solid; Yield: 80\%; mp $160-161{ }^{\circ} \mathrm{C} .{ }^{1} \mathrm{H}$ $\operatorname{NMR}\left(300 \mathrm{MHz}, \mathrm{CDCl}_{3}\right) \delta(\mathrm{ppm}) 3.89(\mathrm{~s}, 3 \mathrm{H}) 7.01(d, J 9.0 \mathrm{~Hz}, 2 \mathrm{H}), 7.19(t, J 8.6 \mathrm{~Hz}, 2 \mathrm{H}), 7.95(d, J 8.8 \mathrm{~Hz}, 2 \mathrm{H})$, $8.00(d d, J 8.8,5.1 \mathrm{~Hz}, 2 \mathrm{H}) ;{ }^{13} \mathrm{C} \mathrm{NMR}\left(75 \mathrm{MHz} \mathrm{CDCl}_{3}\right) \delta(\mathrm{ppm})$ 55.52, 114.72, 116.32, 116.62, 122.89, 126.77, $126.81,129.64,129.90,130.02,162.19,162.84,166.17,166.30$ (thiadiazole C), 168.18 (thiadiazole C); HRMS (EI+): $\mathrm{m} / \mathrm{z}$ Calcd. For $\mathrm{C}_{15} \mathrm{H}_{11} \mathrm{FN}_{2} \mathrm{OS}^{+}: 286.0576$; Found: 286.0576

2-(4-Chlorophenyl)-5-(4-methoxyphenyl)-1,3,4-thiadiazole (5i). ${ }^{34}$ [CAS No. 17572-63-3]: White solid; Yield: 85\%; mp190-191 ${ }^{\circ} \mathrm{C}$ (Lit. 186-187 ${ }^{\circ} \mathrm{C}$ ]. ${ }^{1} \mathrm{H}$ NMR (300 MHz, CDCl $) \delta(p p m) 3.89(s, 3 \mathrm{H}) 7.01$ (d, J $\left.8.8 \mathrm{~Hz}, 2 \mathrm{H}\right)$, $7.48(d, J 8.6 \mathrm{~Hz}, 2 \mathrm{H}), 7.95(d d, J 8.8,2.9 \mathrm{~Hz}, 4 \mathrm{H}) ;{ }^{13} \mathrm{C} \mathrm{NMR}\left(75 \mathrm{MHz}, \mathrm{CDCl}_{3}\right) \delta(\mathrm{ppm}) 55.59,114.80,122.91$, $129.04,129.20,129.64,129.75,137.22,162.31,166.33$ (thiadiazole C), 168.43 (thiadiazole C)

2-(4-bromophenyl)-5-(4-methoxyphenyl)-1,3,4-thiadiazole (5j). White solid; Yield: 83\%; mp $215{ }^{\circ} \mathrm{C} ;{ }^{1} \mathrm{H}$ NMR $\left(300 \mathrm{MHz}, \mathrm{CDCl}_{3}\right) \delta(\mathrm{ppm}) 3.89(\mathrm{~s}, 3 \mathrm{H}) 7.01(d, J 8.6 \mathrm{~Hz}, 2 \mathrm{H}), 7.63(d, J 8.4 \mathrm{~Hz}, 2 \mathrm{H}), 7.88(d, J 8.4 \mathrm{~Hz}, 2 \mathrm{H}), 7.96$ $(d, J 8.6 \mathrm{~Hz}, 2 \mathrm{H}) ;{ }^{13} \mathrm{C} \mathrm{NMR}\left(75 \mathrm{MHz}, \mathrm{CDCl}_{3}\right) \delta$ (ppm) 55.59, 114.77, 122.85, 125.52, 129.36, 129.73, 132.59, 162.28, 166.41 (thiadiazole C), 168.45 (thiadiazole C); HRMS (El+): m/z Calcd. For: $\mathrm{C}_{15} \mathrm{H}_{11} \mathrm{BrN}_{2} \mathrm{OS}^{+}: 345.9775$; Found: 345.9764

2,5-Bis-(4-methoxyphenyl)-1,3,4-thiadiazole (5k) ${ }^{35}$ [CAS No. 17453-03-1]. White solid; Yield: 78\%; mp 167-169 ${ }^{\circ} \mathrm{C}\left[\right.$ Lit. $\left.170-172{ }^{\circ} \mathrm{C}\right] .{ }^{1} \mathrm{H}$ NMR $\left(300 \mathrm{MHz}, \mathrm{CDCl}_{3}\right) \delta(\mathrm{ppm}) 3.88(\mathrm{~s}, 6 \mathrm{H}), 7.00($ d, J $8.8 \mathrm{~Hz}, 4 \mathrm{H}), 7.94(d, J 8.8 \mathrm{~Hz}, 4 \mathrm{H})$; ${ }^{13} \mathrm{C} \mathrm{NMR}\left(75 \mathrm{MHz}, \mathrm{CDCl}_{3}\right) \delta$ (ppm) 55.58, 114.72, 123.28, 129.61, 162.06, 167.40 (thiadiazole C)

2-(3,5-Dimethoxyphenyl)-5-(4-methoxyphenyl)-1,3,4-thiadiazole (5I). Light beige solid; Yield: 75\%; $\mathrm{mp} \mathrm{134-}$ $135{ }^{\circ} \mathrm{C} .{ }^{1} \mathrm{H}$ NMR $\left(300 \mathrm{MHz}, \mathrm{CDCl}_{3}\right) \delta(\mathrm{ppm}) 3.88(s, 6 \mathrm{H}), 3.89(s, 3 \mathrm{H}), 6.59(t, J 2.3 \mathrm{~Hz}, 1 \mathrm{H}), 7.01(d, J 8.8 \mathrm{~Hz}, 2$ $\mathrm{H}), 7.16(d, J 2.3 \mathrm{~Hz}, 2 \mathrm{H}), 7.95(d, J 8.8 \mathrm{~Hz}, 2 \mathrm{H}) ;{ }^{13} \mathrm{C} \mathrm{NMR}\left(75 \mathrm{MHz}, \mathrm{CDCl}_{3}\right) \delta$ (ppm) 55.57, 55.72, 103.42, 105.94, $114.74,123.05,129.69,132.13,161.41,162.22,167.56$ (thiadiazole C), 168.25 (thiadiazole C); HRMS (EI+): $m / z$ Calcd. for $\mathrm{C}_{17} \mathrm{H}_{16} \mathrm{~N}_{2} \mathrm{O}_{3} \mathrm{~S}^{+}$: 328.0882; Found: 328.0869

2-(4-Ethylphenyl)-5-(4-methoxyphenyl)-1,3,4-thiadiazole $(5 \mathrm{~m})$. White solid; Yield: $85 \%$; mp $101-102{ }^{\circ} \mathrm{C} .{ }^{1} \mathrm{H}$ $\operatorname{NMR}\left(300 \mathrm{MHz}, \mathrm{CDCl}_{3}\right) \delta(\mathrm{ppm}) 1.28(t, J 7.6 \mathrm{~Hz}, 3 \mathrm{H}), 2.72(q, J 7.5 \mathrm{~Hz}, 2 \mathrm{H}), 3.89(\mathrm{~s}, 3 \mathrm{H}), 7.01(d, J 9.0 \mathrm{~Hz}, 2 \mathrm{H})$, $7.32(d, J 8.3 \mathrm{~Hz}, 2 \mathrm{H}), 7.96(d, J 9.0 \mathrm{~Hz}, 2 \mathrm{H}), 7.92(d, J 8.3 \mathrm{~Hz}, 2 \mathrm{H}) ;{ }^{13} \mathrm{C} \mathrm{NMR}\left(75 \mathrm{MHz}, \mathrm{CDCl}_{3}\right) \delta(\mathrm{ppm}) 15.35$, 28.88, 55.56, 114.68, 123.16, 127.99, 128.07, 128.84, 129.63, 147.85, 162.06, 167.72 (thiadiazole C), 167.76 (thiadiazole C); HRMS (EI+): $m / z$ Calcd. For $\mathrm{C}_{17} \mathrm{H}_{16} \mathrm{~N}_{2} \mathrm{OS}^{+}$: 296.0983; Found: 296.1002

Procedure for synthesis of compound $(8)^{27,28}$

In a round-bottom flask, following flame drying, $40 \mathrm{ml}$ of $1 \mathrm{M}$ phenylmagnesium bromide (40 mmol) in THF was added. It was then cooled to $0{ }^{\circ} \mathrm{C}$, and $2.42 \mathrm{ml}$ of carbon disulfide $(40 \mathrm{mmol})$ was slowly introduced dropwise. It was stirred at room temperature for $12 \mathrm{hr}$ and then poured into $100 \mathrm{~g}$ of ice water and $3.78 \mathrm{~g}$ of chloroacetic acid $(40 \mathrm{mmol})$. Anhydrous sodium carbonate $3.36 \mathrm{~g}(20 \mathrm{mmol})$ was added and stirred for $24 \mathrm{hr}$ at $90{ }^{\circ} \mathrm{C}$. The liquid was adjusted to $\mathrm{pH} 2$ with concentrated hydrochloric acid, and a red solid was obtained by recrystallization in a mixture of ethyl acetate and hexane. 
2-(Phenylcarbonothionylthio)acetic acid (8) [CAS No. 942-91-6]. Yield: $72 \% ; \mathrm{mp} 125-126{ }^{\circ} \mathrm{C}$ [Lit. $123-125{ }^{\circ} \mathrm{C}$ ]. ${ }^{1} \mathrm{H}$ NMR $\left(300 \mathrm{MHz}, \mathrm{CDCl}_{3}\right) \delta(\mathrm{ppm}) 4.28(s, 2 \mathrm{H}), 7.41(t, J 7.7 \mathrm{~Hz}, 2 \mathrm{H}), 7.57(t, J 7.5 \mathrm{~Hz}, 1 \mathrm{H}), 8.03(d, J 7.9 \mathrm{~Hz}, 2$ H), 10.52 (br. s., $1 \mathrm{H}$ ) ; ${ }^{13} \mathrm{C} \mathrm{NMR} \mathrm{(75} \mathrm{MHz,} \mathrm{CDCl}_{3}$ ) $\delta$ (ppm) 38.76, 127.23, 128.69, 133.18, 144.20, 173.86, 225.89. Procedure for synthesis of compound $9^{28}$

Compound 8 (2.0 g, $9.4 \mathrm{mmol})$ was dissolved in $1 \mathrm{M} \mathrm{NaOH}(10 \mathrm{~mL}, 1 \mathrm{eq})$ and $\mathrm{H}_{2} \mathrm{O}(10 \mathrm{ml})$. Upon addition of hydrazine hydrate $(1.7 \mathrm{~g}, 55 \%, 18.8 \mathrm{mmol})$, the orange color disappeared. After consumption of the starting material, the reaction mixture was acidified to $\mathrm{pH} \mathrm{5-6} \mathrm{with} \mathrm{dilute} \mathrm{HCl}(\mathrm{aq})$ and stirred for $1 \mathrm{hr}$ while cooling in an ice bath. A white solid was filtered and recrystallized from water to produce benzothiohydrazide (9) as white crystals.

Benzothiohydrazide (9) [CAS No. 20605-40-7]. White solid; Yield: 60\%; mp 80-82 ${ }^{\circ} \mathrm{C}\left[\right.$ Lit. $78-80{ }^{\circ} \mathrm{C}$ ]. ${ }^{1} \mathrm{H} \mathrm{NMR}$ $\left(300 \mathrm{MHz}, \mathrm{CDCl}_{3}\right) \delta$ (ppm) 6.25 (br. s., $\left.1 \mathrm{H}\right), 7.37-7.46(\mathrm{~m}, 3 \mathrm{H}), 7.70($ d, J $7.0 \mathrm{~Hz}, 2 \mathrm{H}), 12.13($ br. s., $1 \mathrm{H}) ;{ }^{13} \mathrm{C}$ $\operatorname{NMR}\left(75 \mathrm{MHz}, \mathrm{CDCl}_{3}\right) \delta$ (ppm) 127.82, 129.63, 129.69, 131.64, 167.97.

Procedure for synthesis of compound $\left(4^{\prime}\right)^{29}$

In a round-bottom flask, benzaldehyde $(0.5 \mathrm{mmol})$ and $9(0.5 \mathrm{mmol})$ were added in ethanol $(5 \mathrm{ml})$ for $2 \mathrm{hr}$ at room temperature. After the reaction was complete, the ethanol was evaporated under vacuum, and the product was obtained by recrystallization in a mixture of ethyl acetate and hexane.

2,5-Diphenyl-2,3-dihydro-1,3,4-thiadiazole (4') [CAS No. 82243-06-9]. Yield: 92\%; mp 78-79 ${ }^{\circ} \mathrm{C}\left[\right.$ Lit. $76-78{ }^{\circ} \mathrm{C}$ ]. ${ }^{1} \mathrm{H}$ NMR $\left(300 \mathrm{MHz}, \mathrm{CDCl}_{3}\right) \delta(\mathrm{ppm}) 6.36(\mathrm{~s}, 1 \mathrm{H}, \mathrm{C}-5 \mathrm{H}), 7.29-7.42(\mathrm{~m}, 6 \mathrm{H}), 7.43-7.53(\mathrm{~m}, 2 \mathrm{H}), 7.61-7.75(\mathrm{~m}, 2$ $\mathrm{H}) ;{ }^{13} \mathrm{C}$ NMR $\left(75 \mathrm{MHz} \mathrm{CDCl}_{3}\right) \delta(\mathrm{ppm}) 74.72$ (C-5), 126.65, 127.21, 128.69, 129.12, 129.25, 129.81, 131.37, 140.93, 146.65 .

\section{Acknowledgements}

This work was supported by the GRRC program of Gyeonggi province. [GRRCkyunghee2018-B04]

\section{References}

1. Martins, P.; Jesus, J.; Santos, S.; Raposo, L. R.; Roma-Rodrigues, C.; Baptista, P.V.; Fernandes, A.R.

Molecules 2015, 20, 16852

https://doi.org/10.3390/molecules200916852

2. Hu, Y.; Li, C.Y.; Wang, X.M.; Yang, Y. H.; Zhu, H.L. Chem. Rev. 2014, 114, 5572

https://doi.org/10.1021/cr400131u

3. Balaban, A.T.; Oniciu, D.C.; Katritzky, A.R. Chem. Rev. 2004, 104, 2777

https://doi.org/10.1021/cr0306790

4. Glossman-Mitnik, D. J. Mol. Struct.: THEOCHEM 2001, 549, 285

https://doi.org/10.1016/S0166-1280(01)00550-4

5. Alamajan, G.L.; Barbucescu, S-F.; Baricescu, G.; Saramet, I. Saramet, G.; Draghici, C. Eur. J. Med. Chem. 2010, 45, 6139

6. Al-Soud, Y.A.; Al-Masoudi, N.A.; Loddo, R.; La Colla, P. Arch. Pharm. Chem. Life Sci. 2008, 341, 365 https://doi.org/10.1002/ardp.200700272

7. Jatav, V.; Mishra, P.; Kashaw, S.; Stables, J.P. Eur. J. Med. Chem. 2008, 43, 1945

https://doi.org/10.1016/j.ejmech.2007.12.003 
8. Liu, F.; Luo, X.Q.; Song, B. A.; Bhadury, P.S.; Yang, S.; Jin, L.H.; Xue, W.; Hu, D.Y. Bioorg. Med. Chem. 2008, 16,3632

https://doi.org/10.1016/j.bmc.2008.02.006

9. Liu, X. H.; Shi, Y.X.; Ma, Y.; Zhang, C.Y.; Dong, W.L.; Pan, L.; Wang, B.L.; Li, B. J.; Li, Z.M. Eur. J. Med. Chem. 2009, 44, 2782 https://doi.org/10.1016/j.ejmech.2009.01.012

10. Zoumpoulakis, P.; Camoutsis, C.; Pairas, G.; Sokovic, M.; Glamoclija, J.; Potamitis, C.; Pitsas, A. Bioorg. Med. Chem. 2012, 20, 1569

https://doi.org/10.1016/j.bmc.2011.12.031

11. Foroumadi, A.; Mirzaei, M.; Shafiee, A. Farmaco 2001, 56, 621

https://doi.org/10.1016/S0014-827X(01)01099-0

12. Karakus, S.; Rollas, S. Farmaco 2002, 57, 577

https://doi.org/10.1016/S0014-827X(02)01252-1

13. Talath, S.; Gadad, A.K. Eur. J. Med. Chem. 2006, 41, 918

https://doi.org/10.1016/j.ejmech.2006.03.027

14. Kumar, D.; Kumar, N.M.; Chang, K.H.; Shah, K. Eur. J. Med. Chem. 2010, 45, 4664

https://doi.org/10.1016/j.ejmech.2010.07.023

15. Sasikumar, P.G.N.; Ramaachandra, M.; Naremaddepalli, S.S. PCT Int. Appl. 033301, 2015

16. Carvalho, S.A.; Lopes, F.A.S.; Salomão, K; Romeiro, N.C.; Wardell, S.M.S.V.; de Castro, S.L.; da Silva, E.F.;

Fraga, C.A.M. Bioorg. Med. Chem. 2008, 16, 413

https://doi.org/10.1016/j.bmc.2007.09.027

17. Ali, T.E.S.; El-Kazak, A.M. Eur. J. Chem. 2010, 1, 6

https://doi.org/10.5155/eurjchem.1.1.6-11.12

18. Selvarasu, C.; Kannan, P. J. Chem. Sci. 2015, 127, 1831

https://doi.org/10.1007/s12039-015-0949-0

19. Pathak, S.K.; Nath, S.; De, J.; Pal, S.K.; Achalkumar, A.S. New J. Chem. 2017, 41, 4680

https://doi.org/10.1039/C7NJ00911A

20. Epishina, M.A.; Kulikov, A.S.; Ignat'ev, N.V.; Schulte, M. Mendeleev Commun. 2011, 21, 331

https://doi.org/10.1016/j.mencom.2011.11.013

21. Farrar, J.M.; Patel, M.K.; Kaszynski, P.; Young, V.G. J. Org. Chem. 2000, 65, 931

https://doi.org/10.1021/jo991126l

22. Shahcheragh, S.M.; Habbi, A.; Khosravi, S. Tetrahedron Lett. 2017, 855

https://doi.org/10.1016/j.tetlet.2017.01.057

23. Linganna, N.; Lokanatha Rai, K.M. Synth. Commun. 1998, 28, 4611

https://doi.org/10.1080/00397919808004526

24. Lecher, H.Z.; Greenwood, R.A.; Whitehouse, K.C.; Chao, T.H. J. Am. Chem. Soc. 1956, 78, 5018 https://doi.org/10.1021/ja01600a058

25. Rauchfuss, T.B.; Zank, G.A. Tetrahedron Lett. 1986, 27, 3445

https://doi.org/10.1016/S0040-4039(00)84818-2

26. Jesberger, M.; Davis, T.P.; Barner, L. Synthesis, 2003, 1929

27. Lu, J-T.; Chen, S-S.; Du, M.; Tang, L-F. Appl. Organometal. Chem. 2006, 20, 448 https://doi.org/10.1002/aoc.1087

28. Liu, H.Q.; Wang, D.C.; Wu, F.; Tang, W.; Ouyang, P.K. Chin. Chem. Lett. 2013, 24, 929 https://doi.org/10.1002/aoc.1087 
29. Evans, D.M.; Taylor, D.R. J. Chem. Soc., Chem. Commun. 1982, 3, 188

https://doi.org/10.1039/C39820000188

30. Bergman, J.; Pettersson, B.; Hasimbegovic, V.; Svensson, P.H. J. Org. Chem. 2011, 76, 1546 https://doi.org/10.1021/jo101865y

31. Ascherl, L.; Nordheider, A.; Athukorala Arachchige, K.S.; Cordes, D.B.; Karaghiosoff, K.; Bühl, M.; Slawina, A.M.Z.; Woollins, J.D. Chem. Commun. 2014, 50, 6214 https://doi.org/10.1039/C4CC01073F

32. Srivastava, V.; Singh, P.K.; Singh, P.P. Croat. Chem. Acta 2015, 88, 59 https://doi.org/10.5562/cca2520

33. Kumar, D.; Pilania, M.; Arun, V.; Pooniya, S. Org. Biomol. Chem. 2014, 12, 6340 https://doi.org/10.1039/C4OB01061B

34. Siegrist, A.E.; Maeder, E.; Duennenberger, M.; Liechti, P. Patentschrift (Switz) 1967, CH426828 19670630; Chem. Abstr. 1968, 69002

35. Zarei, M. Tetrahedron 2017, 73, 1867. https://doi.org/10.1016/j.tet.2017.02.042 